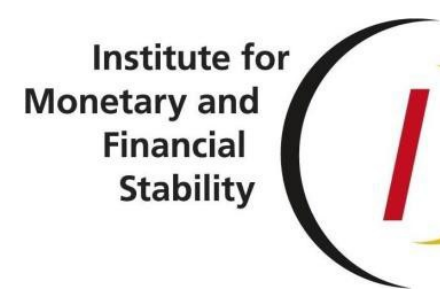

JOHN B. TAYLOR

VOLKER WIELAND

\title{
Finding the Equilibrium Real Interest Rate in a Fog of Policy Deviations
}

Institute for Monetary and Financial Stability

GOETHE UNIVERSITY FRANKFURT AM MAIN 
This Working Paper is issued under the auspices of the Institute for Monetary and Financial Stability (IMFS). Any opinions expressed here are those of the author(s) and not those of the IMFS. Research disseminated by the IMFS may include views on policy, but the IMFS itself takes no institutional policy positions.

The Institute for Monetary and Financial Stability aims at raising public awareness of the importance of monetary and financial stability. Its main objective is the implementation of the "Project Monetary and Financial Stability" that is supported by the Foundation of Monetary and Financial Stability. The foundation was established on January 1, 2002 by federal law. Its endowment funds come from the sale of $1 \mathrm{DM}$ gold coins in 2001 that were issued at the occasion of the euro cash introduction in memory of the D-Mark.

The IMFS Working Papers often represent preliminary or incomplete work, circulated to encourage discussion and comment. Citation and use of such a paper should take account of its provisional character.

\section{Institute for Monetary and Financial Stability}

Goethe University Frankfurt

House of Finance

Theodor-W.-Adorno-Platz 3

D-60629 Frankfurt am Main

www.imfs-frankfurt.de I info@imfs-frankfurt.de 


\title{
Finding the Equilibrium Real Interest Rate in a Fog of Policy Deviations ${ }^{1}$
}

John B. Taylor and Volker Wieland

April 2016

\begin{abstract}
Recently there has been an explosion of research on whether the equilibrium real interest rate has declined, an issue with significant implications for monetary policy. A common finding is that the rate has declined. In this paper we provide evidence that contradicts this finding. We show that the perceived decline may well be due to shifts in regulatory policy and monetary policy that have been omitted from the research. In developing the monetary policy implications, it is promising that much of the research approaches the policy problem through the framework of monetary policy rules, as uncertainty in the equilibrium real rate is not a reason to abandon rules in favor of discretion. But the results are still inconclusive and too uncertain to incorporate into policy rules in the ways that have been suggested.
\end{abstract}

\footnotetext{
${ }^{1}$ This paper is based in part on results presented at the NABE Panel "The Equilibrium Real Interest Rate-Theory, Measurement, and Use in Monetary Policy" organized by George Kahn at the ASSA meeting in San Francisco on January 3, 2016.
} 


\section{Introduction}

A large number of economic research papers have recently been written endeavoring to estimate the current level and trend in the equilibrium real interest rate. Examples include Barsky, Justiniano and Melosi (2014), Curdia (2015), Curdia, Ferrero, Ng and Tambalotti (2015), Justiniano and Primiceri (2012), Kiley (2015), Laubach and Williams (2015), and Lubik and Matthes (2015). These studies are generally model-based: they either use semi-structural time-series and filtering methods or formal structural dynamic stochastic general equilibrium (DSGE) macroeconomic models to examine the relationship between the equilibrium real interest rate and its possible determinants. A common finding in these studies is that the equilibrium real interest rate has declined in recent years to a level not seen in decades.

The explosion of this research is not surprising. The results have important implications for monetary policy as discussed in Carlstrom and Fuerst (2016), Dupor (2015), Hamilton, Harris, Hatzius and West (2015), Summers (2014) and Yellen (2015). Indeed, several U.S. policy making or policy advising organizations have reported estimates or ranges of estimates of the equilibrium real interest rate based on such studies, including the Congressional Budget Office, the Office of Management and Budget, the Federal Open Market Committee, as well as professional forecasters and financial market participants, as Cieslak (2015) has documented. Many of the recommendations for monetary policy are in the form of how the central bank's monetary policy rule should be adapted, modified, or even thrown out in light of the findings.

Although much of the research is new, it can be traced to a 2003 paper by Laubach and Williams (2003) on estimating the equilibrium interest rate. Until that time, as the authors then noted, "the problem of real-time estimation of the natural rate of interest has received 
surprisingly little attention” with one exception being Rudebusch’s (2001) analysis of the stance of monetary policy. Prior to this period virtually all work on measurement uncertainty relating to monetary policy rules was about estimates of potential GDP or measures of inflation, rather than the equilibrium real interest rate.

In this paper we examine the underlying methodology used in these model-based estimates. First, we show that the estimates are subject to omitted variable or even omitted equation bias. What appear to be trends in the equilibrium interest rate may instead be trends in other policy variables that affect the economy. While such problems have always made it difficult to find and estimate concepts such as the equilibrium real interest rate, recent changes in policy variables have deepened the fog. Second, we show that methods used to adjust monetary policy rules to take account of shifts in the equilibrium interest rate alone are incomplete and misleading because they do not incorporate other shifts—such as changes in potential GDP—-that are associated with the shifts. These shifts need to be accounted for when the results are applied to monetary policy decisions or rules. Finally, we show that alternative simulation techniques can radically alter the results. In sum we conclude that the estimates of time-varying real equilibrium interest rates that have emerged from recent research are not yet useful for application to current monetary policy.

\section{A Simple Framework and Omitted Variables Problems}

The real equilibrium interest rate is usually defined as the real interest rate consistent with the economy reaching both potential output and price stability. In other words, it is the real interest rate where real GDP equals potential GDP and the inflation rate equals the target inflation rate. ${ }^{2}$ The semi-structural time-series and DSGE models used to find this equilibrium

\footnotetext{
${ }^{2}$ For example, this is the definition used in Yellen (2015).
} 
real interest rate are complex and difficult to understand intuitively, but the logic — and thereby the pitfalls_ — can be explained in simple terms if we focus on three relationships common to macroeconomic models. The methodology described here is closest to that used by Laubach and Williams (2015), but we think it also applies to the model-based studies such as Barsky, Justiniano and Melosi (2014), Curdia et al (2015), or Justiniano and Primiceri (2012). ${ }^{3}$

The first relationship is the intertemporal substitution equation (aka Euler equation or IS curve) between real GDP and the real interest rate. For simplicity we can write this as a linear equation in terms of percentage deviations of real GDP from potential GDP and the deviations of the real interest rate from the equilibrium real interest rate:

$$
y-y^{*}=-\beta\left(r-r^{*}\right)
$$

where $\mathrm{y}$ is the $\log$ of real GDP, $\mathrm{y}^{*}$ is the log of potential GDP, $\mathrm{r}$ is the real interest rate and $\mathrm{r}^{*}$ is the equilibrium real interest rate. Assume that we have time series observations on y and r, and that the parameter $\beta$ can be calibrated or estimated.

The second relationship is about price adjustment. Again for simplicity assume that it too can be represented as a linear equation, this time between the rate of inflation and the gap between real GDP and potential GDP

$$
\pi=\pi(-1)+\theta\left(y-y^{*}\right)
$$

\footnotetext{
${ }^{3}$ Here we abstract from differences in timing of equilibrium and the definition of potential GDP. For example, some of the DSGE studies have focused on short-run equilibria that depend on economic shocks rather than the mediumor longer-run levels that are reached when the effects of shocks have been partly or fully resolved.
} 
where $\pi$ is the inflation rate. This equation could easily be generalized to incorporate staggered wage setting, expectations, or indexing as in a typical new Keynesian model, but the logic of the argument would not change. Note that having the gap on the right-hand side, implies that y being equal to $\mathrm{y}^{*}$ is consistent with price stability (steady inflation at a target, such as 2 percent). We assume that we have observations on $\pi$ and that the parameter $\theta$ can also be calibrated or estimated.

Model-based studies focus on these two relationships and the task is to use them to find the equilibrium real rate of interest $\mathrm{r}^{*}$. If one knew potential GDP $\left(\mathrm{y}^{*}\right)$, then a seemingly reasonable method for finding $\mathrm{r}^{*}$ would be to see if equation (1) generates an output gap (y-y*) that is different from what is predicted, $P\left(\mathrm{y}-\mathrm{y}^{*}\right)$, based on information on the right hand side. If there is a difference, then one must adjust (the estimate of) $r^{*}$ up or down until it gives the correct prediction. For example, if $\left(\mathrm{y}^{-} \mathrm{y}^{*}\right)<\mathrm{P}\left(\mathrm{y}-\mathrm{y}^{*}\right)$, then $\mathrm{r}^{*}$ is too high and it must be lowered.

Of course, $\mathrm{y}^{*}$ is also unknown, but equation (2) can be used to help find it following the same logic used to find $r^{*}$ : If $\pi$ is not equal to the prediction, $P \pi$, from equation (2), then adjust $\mathrm{y}^{*}$. For example, if $\pi>P \pi$, then lower (the estimate of) $\mathrm{y}^{*}$.

Now consider the omitted variable problem. Suppose that another variable, or several variables, can shift the intertemporal relationship in equation (1) around. For example, costly regulations might lower the level of investment demand associated with a given real interest rate. This would mean that rather than equation (1) we would have equation (1')

$$
y-y^{*}=-\beta\left(r-r^{*}\right)-\alpha x^{*}
$$


where the variable $\mathrm{x}^{*}$ could represent a variety of influences on real GDP from regulations that negatively affect investment to tax policy that negatively affects consumption. With equation (1'), if one finds that $y-y^{*}$ is lower than the prediction $P\left(y-y^{*}\right)$, then the implication is not necessarily that the estimate of $\mathrm{r}^{*}$ is too high and must be lowered. Now there is the possibility that $\mathrm{X}^{*}$ is too low and must be raised. In other words, the possibility of an omitted variable that is not in the macro model makes it more difficult to find the equilibrium real interest rate.

There is also another important problem of omission which makes it even more difficult to find $\mathrm{r}^{*}$. According to most macroeconomic models, there is also a financial sector and a central bank reaction function which create another relationship. To capture this relationship suppose we add a monetary policy rule to the model which makes the nominal interest rate and thus the real interest rate endogenous:

$$
\mathrm{i}=\pi+.5(\pi-2)+.5\left(\mathrm{y}-\mathrm{y}^{*}\right)+\mathrm{r}^{*}+\mathrm{d}^{*}
$$

where $\mathrm{i}$ is the nominal interest rate set by the central bank and $\mathrm{d}^{*}$ is a possible deviation from the policy implied by the rule. As with equations (1) and (2), if $\mathrm{i}$ is not equal to the prediction $P \mathrm{i}$, then one can adjust $r^{*}$, but one can also adjust $d^{*}$. For example, if $i<P i$ then one might conclude that it reflects a lower $\mathrm{r}^{*}$, but an alternative interpretation is a decline in $\mathrm{d}^{*}$. In fact, given what has happened to monetary policy in recent years around the globe it would be a big mistake not to consider this. In the following charts, which are updates of charts created by Hofmann \& Bogdanova (2012) at the BIS, Hyun Shin (2016) shows how large and significant 
the variable $\mathrm{d}^{*}$ has been around the world recently when the policy rule is the Taylor rule and $\mathrm{r}^{*}$ is calibrated with respect to the estimated trend of output growth. ${ }^{4}$

Global

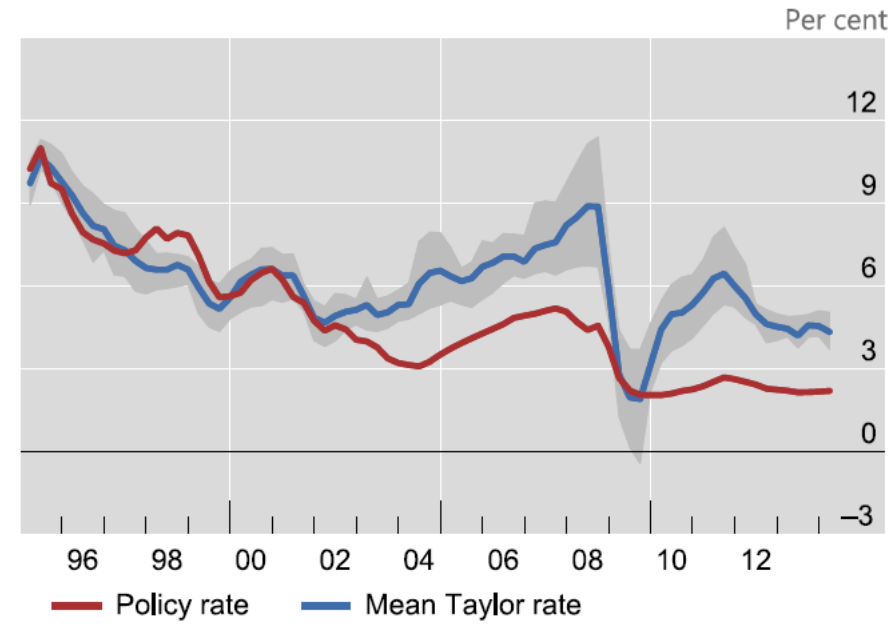

Emerging markets

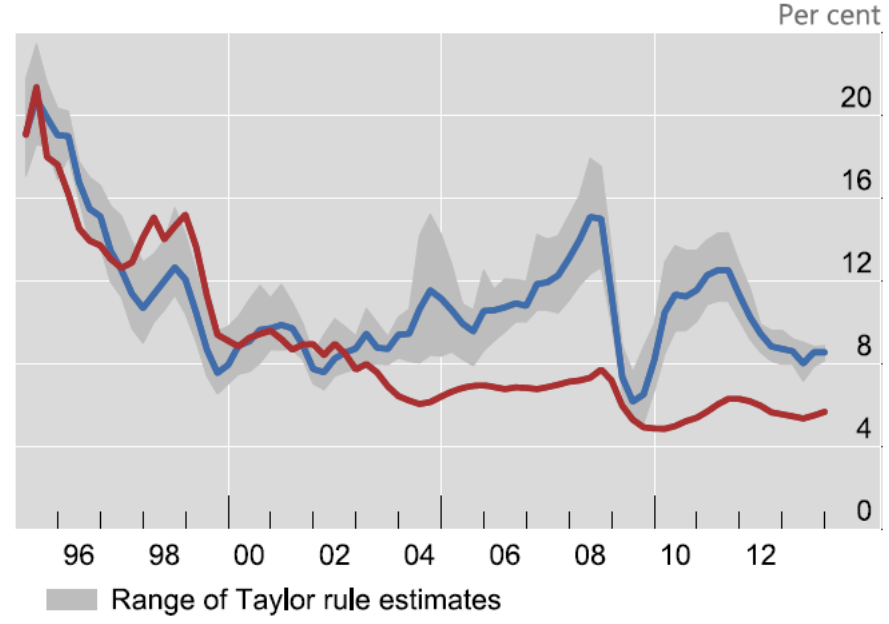

Figure 1. The Global Great Deviation in Central Bank Policy Rates

Source: Shin (2016) update of Hofmann \& Bogdanova (2012)

It is our view that the existing studies referred to at the start of this paper underestimate the influence of $\mathrm{x}^{*}$ and $\mathrm{d}^{*}$ in their analysis and their search for the real equilibrium real interest rates. This is easiest to see in the case of Laubach and Williams (2015) who use versions of equation (1) and (2) but it is also a good characterization of the DSGE models which do not include variables such as regulation and tax inefficiencies.

\footnotetext{
${ }^{4}$ Hofmann and Bogdanova (2012) use a thick-modelling approach to capture uncertainty about inflation and output gap measures. The estimated equilibrium real rate is set equal to the respective estimate of the trend growth rate of GDP associated with any of the different output gap definitions considered.
} 


\section{Implication for the Pre-Crisis and Post-Crisis Equilibrium Real Interest Rate}

Let us now consider in more detail the implications of the omitted variables during the past 15 years, the period over which much of the research on the equilibrium real interest rate has been conducted. The story is different for the pre-crisis period, especially from 2003 to 2005, compared to post-crisis period, so we consider each separately.

\section{Pre-Crisis Period}

During the period around 2003-2005, the U.S. economy was generally booming. The unemployment rate got as low as $4.4 \%$ well below the natural rate, a clear indication that $\mathrm{y}$ was greater than $\mathrm{y}^{*}$. There were extraordinary upward pressures in the housing market as demand for homes skyrocketed and home price inflation took off. And overall inflation was rising. The inflation rate measured by the GDP price index doubled from $1.7 \%$ to $3.4 \%$ per year. In sum, there were clear signs of overheating with y greater than $\mathrm{y}^{*}$ and $\pi$ rising.

During this period the Fed held its policy interest rate (the federal funds rate) very low at 1 percent for a "prolonged period" and then increased it very slowly at a "measured pace.” It thus appeared that $\mathrm{r}<\mathrm{r}^{*}$ and, as predicted by equations (1) and (2), this created upward pressures on y and $\pi$. In other words, the model was generally predicting well and there is no reason to think that $\mathrm{r}^{*}$ should have been lower than 2 percent during that period. Since y was above $\mathrm{y}^{*}$, there is no reason to adjust $\mathrm{y}^{*}$ on that account either.

These interest rate settings were below the policy rule in equation (3) for a r* $=2$ and $\mathrm{d}^{*}=$ 0. According to equation (3), this implies either that $\mathrm{r}^{*}$ should be adjusted down, say from 2 percent to 0 percent, or that $d^{*}$ should be adjusted down, say from 0 percent to -2 percent. With no reason to lower the equilibrium rate based on equation (1) and (2), however, the explanation 
must be that policy rate deviated from the policy rule. In fact, there is corroborating evidence for this, including Shin’s (2016) graph in Figure 1. In other words, the evidence points to a policy deviation $\mathrm{d}^{*}$ which shifted the Fed's policy rate down, rather than a decline in $\mathrm{r}^{*}$.

In contrast, note that Summers (2014) argues that r* had fallen in the years before the crisis, when, as he put it, "arguably inappropriate monetary policies and surely inappropriate regulatory policies,” should have caused the economy to overheat. Since Summers also argues that "there is almost no case to be made that the real US economy overheated prior to the crisis" he concludes that $\mathrm{r}^{*}$ should be lower. But in fact, as shown in the previous paragraph, the economy did overheat in that period—whether one looks at labor market pressures, rising inflation, or boom-like housing conditions. By bringing in the third equation and the missing variable $\mathrm{d}^{*}$ one has the alternative explanation given here.

\section{Post-Crisis Period}

Now consider the years after the crisis. During these years, the economic recovery has been very weak as many authors have concluded. The gap between real GDP and potential GDP — at least as measured before the crisis—has not closed by much. Many, including economists at the Federal Reserve Board, predicted that the recovery would be stronger. It is clear that $y-y^{*}$ was lower than forecast with the very low interest rate set by the Federal Reserve. Most of the studies referred to at the start of this paper argue that the forecast error is due to an $r^{*}$ that is lower than we thought, and this gives rise to the idea of a currently low $r^{*}$. If $r^{*}$ is down, then r-r* is not as low as you think. But according to equation (1'), it could either be a lower $\mathrm{r}^{*}$ or a higher $\mathrm{x}^{*}$ that is dragging the economy down at a given real interest rate $\mathrm{r}$. Thus an an alternative explanation is $\mathrm{x}^{*}$ has been the problem. And there is corroborating evidence of 
this. Most of the contributors to the book by Ohanian, Taylor and Wright (2012) argue that the problem is economic policy.

But if you want to point to $\mathrm{x}^{*}$ rather than $\mathrm{r}^{*}$ as the culprit then how do you explain the very low interest rates set by the Federal Reserve and other central banks. Here is where equation (3) and the other omitted variable come in. A decline in r* is not the only reason why the interest rate is low. It could just as well be due to a policy deviation $\mathrm{d}^{*}$. And here there is corroborating evidence. Figure 1 shows that the decline may well be due to a large deviation $\mathrm{d}^{*}$ - what Hofmann and Bogdanova (2012) call a Global Great Deviation—rather than r* being the culprit. In sum there is a perfectly reasonable alternative explanation of the facts if one expands the model as suggested here. Rather than conclude that the real equilibrium interest rate $\mathrm{r}^{*}$ has declined, there is the alternative that economic policy has deviated shifted, whether in the form of regulatory and tax policy $\left(\mathrm{x}^{*}\right)$ or in the form if monetary policy $\left(\mathrm{d}^{*}\right)$. And there is empirical evidence in favor of this explanation.

\section{Implications for Monetary Policy}

Many have explored the policy implications of the research on the real equilibrium interest rate, and this usually is in the context of how to adjust the central bank's monetary policy rules. In an important recent speech, Yellen (2015), for example, showed the effects of allowing a change in the equilibrium real interest rate in the Taylor rule, arguing as follows ${ }^{5}$

“Taylor's rule now calls for the federal funds rate to be well above zero if... the "normal" level of the real federal funds rate is currently close to its historical average. But the prescription offered by the Taylor rule changes significantly if one instead

\footnotetext{
${ }^{5}$ Yellen (2015) uses slightly different notation, such as $\mathrm{RR}^{*}$ rather than $\mathrm{r}^{*}$
} 
assumes, as I do, that the economy's equilibrium real federal funds rate-that is, the real rate consistent with the economy achieving maximum employment and price stability over the medium term-is currently quite low by historical standards. Under assumptions that I consider more realistic under present circumstances, the same rules call for the federal funds rate to be close to zero.”

"For example, the Taylor rule is $\mathrm{R}_{\mathrm{t}}=\mathrm{RR} *+\pi_{\mathrm{t}}+0.5\left(\pi_{\mathrm{t}}-2\right)+0.5 \mathrm{Y}_{\mathrm{t}}$, where $\mathrm{R}$ denotes the federal funds rate, $R^{*}$ is the estimated value of the equilibrium real rate, $\pi$ is the current inflation rate (usually measured using a core consumer price index), and Y is the output gap. The latter can be approximated using Okun's law, $Y_{t}=-2\left(U_{t}-U^{*}\right)$, where $\mathrm{U}$ is the unemployment rate and $\mathrm{U}^{*}$ is the natural rate of unemployment. If $\mathrm{RR}^{*}$ is assumed to equal 2 percent (roughly the average historical value of the real federal funds rate) and $\mathrm{U}^{*}$ is assumed to equal 5-1/2 percent, then the Taylor rule would call for the nominal funds rate to be set a bit below 3 percent currently, given that core PCE inflation is now running close to $1-1 / 4$ percent and the unemployment rate is 5.5 percent. But if RR* is instead assumed to equal 0 percent currently (as some statistical models suggest) and $\mathrm{U}^{*}$ is assumed to equal 5 percent (an estimate in line with many FOMC participants' SEP projections), then the rule's current prescription is less than 1/2 percent.”

Thus if one simply replaces the equilibrium federal funds rate of $2 \%$ in the Taylor rule with $0 \%$, then the recommended setting for the funds rate declines by two percentage points. However, there is a lot of disagreement and uncertainty regarding this rate, and in our view, there are good reasons to think that it has not changed that much. 
In any case this is a controversial and debatable issue, deserving a lot of research. If one can adjust the intercept term (that is, $\mathrm{RR}^{*}$ ) in a policy rule in a purely discretionary way, then it is not a rule at all any more. It's purely discretion. Sharp changes in the equilibrium interest rate need to be treated very carefully. ${ }^{6}$

Moreover, calculations such as in Yellen (2015) are incomplete and misleading because they do not incorporate other shifts—-such as changes in potential GDP—-that are associated with the shifts in r* according to Laubach-Williams (2015) and others. As she describes in her paper, Yellen (2015) shows that if you insert estimates of the equilibrium interest rate computed by Laubach and Williams (2015) into a Taylor rule, you get a lower policy interest rate in the United States than if you assume a 2 percent real rate as in the original version of the rule. However, as the Report of the German Council of Economic Experts (2015) ${ }^{7}$ shows, that's not true if you also insert, along with the estimated real equilibrium interest rate, the associated real output gap estimated with the Laubach-Williams methodology as logic and consistency would suggest. Figure 2 below, drawn from the GCEE Report shows that the effect is very large—more than 2 percentage points. It thus completely reverses the impact of the lower $r^{*}$. The light-green line (labeled Yellen-Taylor rule) shows the Yellen (2015) version of the Taylor rule that uses the estimate of $r^{*}$ from the Laubach-Williams method together with an output gap derived from the unemployment rate using Okun's law with an estimate of the (long-run) NAIRU ${ }^{8}$. The dark

\footnotetext{
${ }^{6}$ Another important rules versus discretion issue illustrated by Yellen's (2015) paper is that she does not make the argument here that the coefficient on the output gap in the Taylor rule should be 1.0 rather than 0.5 as she has in previous speeches advocating a lower interest rate. The argument is different here, and no reason for dropping the old argument is given. Perhaps the reason is that the gap is small now, so the coefficient on the gap does not make much difference. Nevertheless, this gives the impression that one is changing the rule to get a desired result.

${ }^{7}$ One of the authors of this paper, Volker Wieland, is a member of the Council and co-author of the Annual Report.

${ }^{8}$ The calculations shown use the NAIRU estimated by the Congressional Budget office and PCE inflation. The line labeled „standard Taylor rule“ uses the same unemployment-based output gap estimate and PCE inflation together with a constant $r^{*}$ of $2 \%$ as in the original Taylor rule.
} 
green line (labeled consistent Yellen-Taylor Rule) instead uses the r* and the output gap estimated with the Laubach-Williams method together.

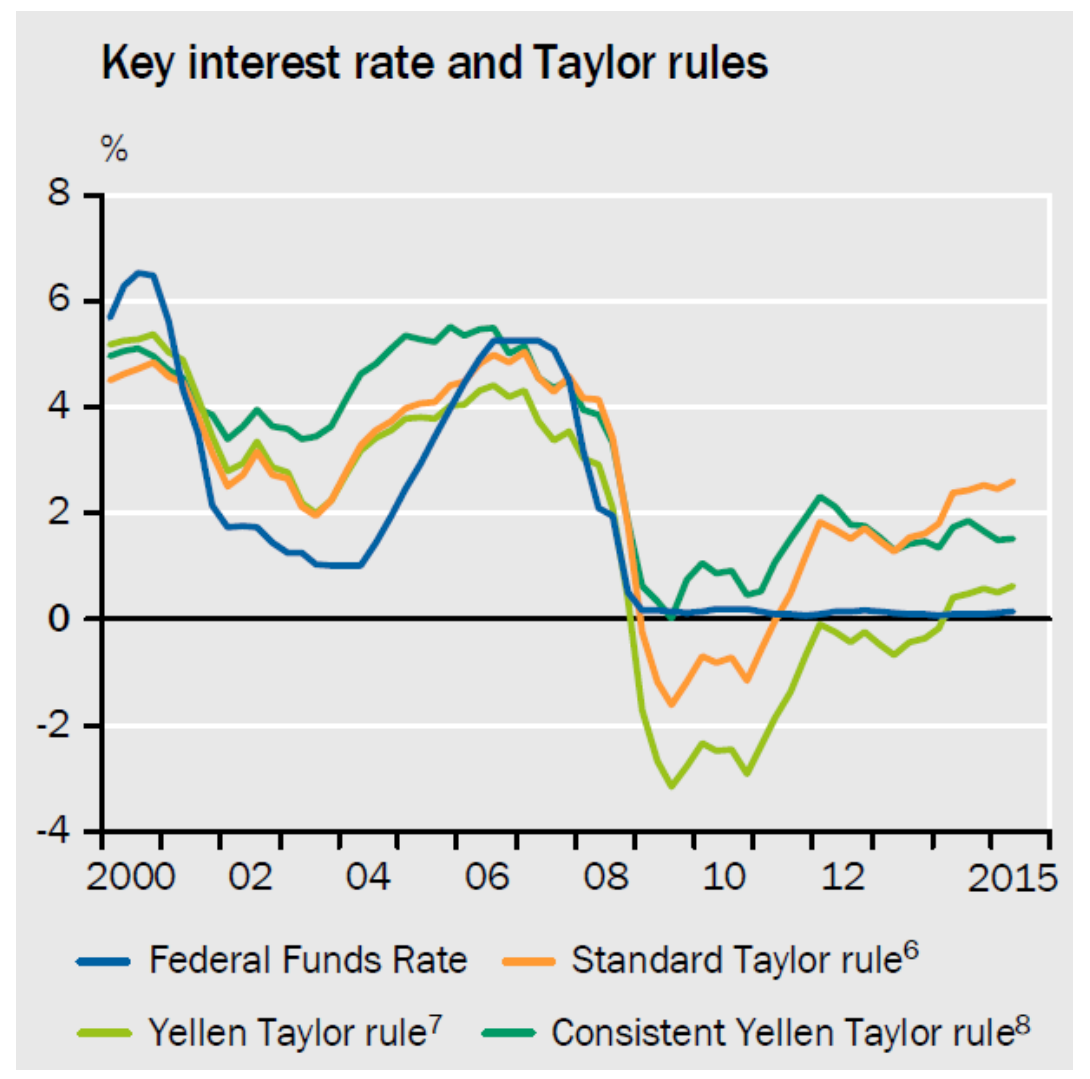

Figure 2. Alternative Methods to Modify Taylor Rule

Source: Annual Report GCEE, Nov 11, 2015

There are several other suggestions for how to adjust monetary rules in light of new estimates of r*. Laubach and Williams (2015) and Hamilton, Harris, Hatzius and West (2015) argue that uncertainty about $\mathrm{r}^{*}$ means that policy makers should use inertial Taylor rules, with a 
lagged interest rate on the right hand side along with other variables. There are other reasons for doing this in the literature and it is not a very radical idea.

Other suggestions are more radical. Curdia, Ferrero, Ng, and Tambalotti (2015) suggest replacing the output gap in the Taylor rule with $\mathrm{r}^{*}$, arguing that economic performance would improve. Barsky, Justiniano, Melosi (2014) suggest doing away with the Taylor rule altogether and just setting the policy interest rate to $\mathrm{r}^{*}$ as it is estimated to move around over time. In our view the estimates of $\mathrm{r}^{*}$ are still way too uncertain, and more evidence about robustness is needed before following these suggestions.

\section{Alternative Simulation Techniques}

Studies that use New Keynesian DSGE models to estimate time-varying equilibrium real interest rates such as, for example, Barsky et al (2014) and Curdia et al (2015), have focused on simulating the path of a short-run equilibrium rate. It is the real interest rate that coincides with the level of output that would result under a fully flexible price level, that is, absent the price level rigidity characteristic of New Keynesian models. This short-run equilibrium rate depends on economic shocks and consequently varies a lot over time. It could even exhibit greater variation than the actual real interest rate.

Of course, DSGE models also contain a long-run equilibrium real interest rate. It is reached in steady-state when the effects of economic shocks have worked themselves out. This is the rate that has typically been used as $\mathrm{r}^{*}$ in model-based evaluations of policy rules of the form of equation (3), including, for example, the comparative studies in Taylor (1999), Levin, Wieland and Williams (2003) and Taylor and Wieland (2012). One of the models considered in the latter comparison is the well-known empirical New Keynesian DSGE model of the United 
States economy estimated by Smets and Wouters (2007). They report an estimate of the steadystate real interest rate of 3 percent based on quarterly data of 2005 vintage covering the period of 1996:Q1 to 2004:Q4.

Figure 3 below, also drawn from the GCEE Report (2015), shows that estimates of the long-run equilibrium real rate have not changed that much. These estimates are based on rolling 20-year windows of real time data. Thus, each quarter the model is fit to the data vintage available at that period in time using the same Bayesian estimation method as Smets and Wouters (2007). The resulting equilibrium rate is about 3 percent in 1994. Afterwards, estimates rises slowly to values closer 4 percent. From 2002 onwards they decline again slowly towards about 3 percent in 2007. In recent years, the long-run equilibrium is estimated a bit above 2 percent. ${ }^{9}$ Thus, estimates of the long-run r* based on a very standard DSGE model vary little and remain well above zero.

\footnotetext{
${ }^{9}$ Estimates of the long-run real rate within such a DSGE model using Bayesian methods depend on empirical averages as well as the model structure including the priors set by the modeler concerning certain structural parameters. The above estimation uses the same priors as Smets and Wouters. There is no prior set on the equilibrium interest rate. It is likely to be influenced by the priors for equilibrium inflation, equilibrium GDP growth, the discount rate and the intertemporal elasticity of substitution. Estimates of the equilibrium interest rate vary less than the 20-year sample averages of the real interest rate.
} 
Estimates of the long-term equilibrium interest rate in the economy of the United States ${ }^{1}$ Recursive estimation with the Smets-Wouters-Model (2007), 20-year-window

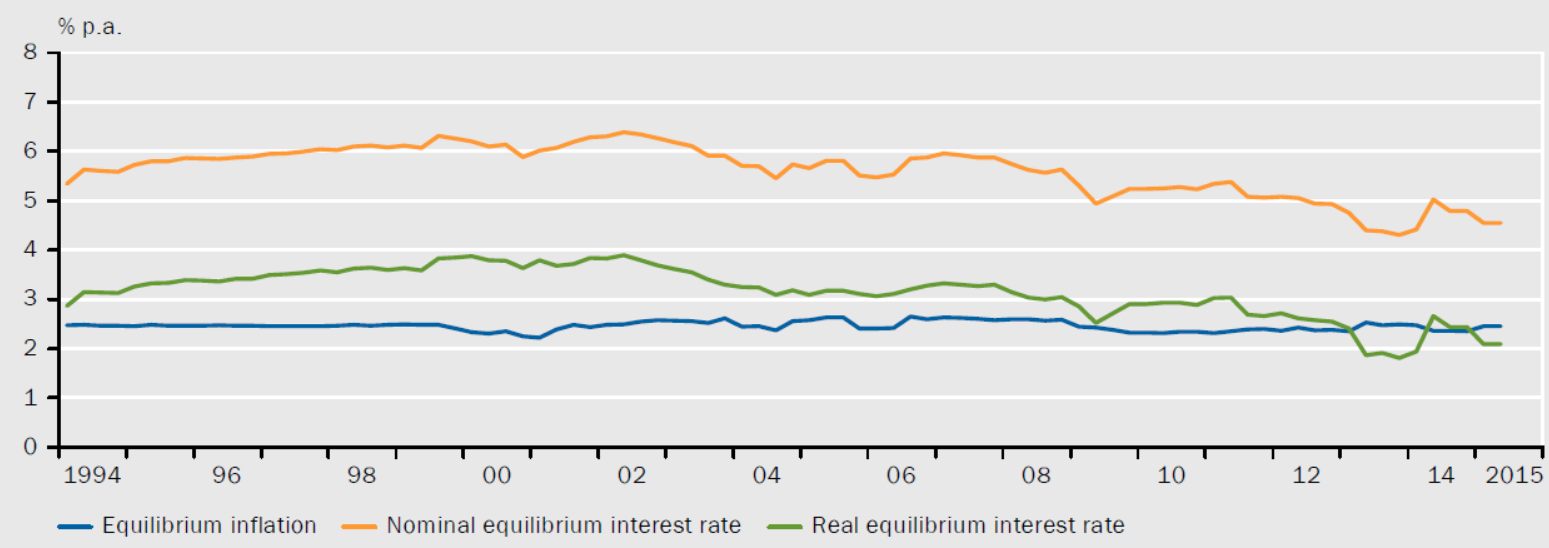

1 - Own calculations

Figure 3: Estimates of long-run $r^{*}$ with the Smets-Wouters model

Source: Annual Economic Report German Council of Economic Experts 2015

Figure 3 also includes estimates of equilibrium inflation, which remain very stable, and the equilibrium nominal interest rate, which mirror the moderate changes in the real rate. The use of rolling 20-year windows implies giving a lot of weight to recent data in estimating the equilibrium rate. If one simply extends the original data range to include the more recent observations, the estimate of the equilibrium rate will decline even less.

\section{Conclusion}

There has been much interesting model-based research recently on the question of whether the equilibrium real interest rate $r^{*}$ has declined or not. However, we do not think this research is yet useful for policy because it omits important variables relating to structural policy and monetary policy. In developing the monetary policy implications, the research is promising in that it approaches the policy problem through the framework of monetary policy rules, as 
uncertainty in the equilibrium real rate is not a reason to abandon rules in favor of discretion. Nevertheless, the results are still inconclusive and too uncertain to incorporate into policy rules in the ways that have been suggested.

Furthermore, there is evidence that contradicts the hypothesis that there has been a significant decline in the equilibrium real interest rate. Instead, the perceived decline found in recent studies may well be due to shifts in regulatory policy and monetary policy that have been omitted from the research. 


\section{References}

Barsky, Robert, Alejandro Justiniano, and Leonardo Melosi (2014), The Natural Rate of Interest and Its Usefulness for Monetary Policy,” American Economic Review: Papers \& Proceedings, 104(5): 37-43.

Carlstrom and Charles T. and Timothy S. Fuerst (2016), “The Natural Rate of Interest in Taylor Rules,” Economic Commentary, No. 2016-01, Federal Reserve Bank of Cleveland.

Cieslak, Anna (2015) "Discussion of 'The Equilibrium Real Funds Rate: Past, Present and Future,’” by James D. Hamilton, Ethan S. Harris, Jan Hatzius, Kenneth D. West (2015), slides from Brookings Conference, http://www.brookings.edu/ /media/Events/2015/10/interestrates/Disc_HHHW_02.pdf?la=en.

Curdia, Vasco (2015), "Why So Slow? A Gradual Return for Interest Rates,” FRBSF Economic Letter, October 12.

Curdia, Vasco, Andrea Ferrero, Ging Cee Ng, Andrea Tambalotti (2015), "Has U.S. Monetary Policy Tracked the Efficient Interest Rate?” Journal of Monetary Economics, Vol. 70(C), 72-83.

Dupor, William (2015) “Liftoff and the Natural Rate of Interest”, Economic Synopsis, No. 12 Federal Reserve Bank of St. Louis.

German Council of Economic Experts (2015) Focus on Future Viability Annual Economic Report, November 11.

Hamilton, James D., Ethan S. Harris, Jan Hatzius, Kenneth D. West (2015), “The Equilibrium Real Funds Rate: Past, Present and Future,” paper for the U.S. Monetary Policy Forum, New York City, February 27.

Hofmann, Boris and Bilyana Bogdanova, 2012, Taylor Rules and Monetary Policy: A Global Great Deviation? BIS Quarterly Review, September.

Justiniano, Alejandro and Giorgio E. Primiceri (2010) "Measuring the equilibrium real interest rate,” Economic Perspectives, Federal Reserve Bank of Chicago.

Kiley, Michael T. (2015), "What Can the Data Tell Us About the Equilibrium Real Interest Rate?” Board of Governors of the Federal Reserve, FEDS Working Paper No. 2015-077.

Laubach, Thomas and John C. Williams, 2003, “Measuring the Natural Rate of Interest,” The Review of Economics and Statistics 85(4): 1063-1070.

Laubach, Thomas and John C. Williams, 2015, "Measuring the Natural Rate of Interest Redux," Federal Reserve Bank of San Francisco. 
Levin, Andrew, John C. Williams and Volker Wieland (2003), The Performance of ForecastBased Monetary Policy Rules under Model Uncertainty, American Economic Review, 93 (3), June.

Lubik, Thomas A. and Christian Matthes (2015), "Calculating the Natural Rate of Interest: A Comparison of Two Alternative Approaches,” Economic Brief, Federal Reserve Bank of Richmond, October.

Orphanides, Athanasios, and John C. Williams, (2002), "Robust Monetary Policy Rules with Unknown Natural Rates,” Brookings Papers on Economic Activity, 2, 63-145.

Rudebusch, Glenn D. (2001), "Is the Fed Too Timid? Monetary Policy in an Uncertain World," (2001) Review of Economics and Statistics 83:2 203-217.

Shin, Hyun (2016) "Macroprudential Tools, Their Limits, and Their Connection with Monetary Policy" in Olivier Blanchard, Raghuram Rajan, Kenneth Rogoff, and Lawrence H. Summers (Eds.), Progress and Confusion: The State of Macroeconomic Policy, MIT Press.

Smets, Frank and Raf Wouters (2007), Shocks and Frictions in US Business Cycles: A Bayesian DSGE Approach, American Economic Review, 97:3, 586-606, June.

Summers, Lawrence H. (2014), "Low Equilibrium Real Rates, Financial Crisis, and Secular Stagnation,” in Martin Neil Baily, John B. Taylor (Eds.) Across the Great Divide: New Perspectives on the Financial Crisis. Hoover Press, Stanford, pp. 37-50 http://www.hoover.org/sites/default/files/across-the-great-divide-ch2.pdf.

Taylor, John B.(1999) (ed.), Monetary Policy Rules, University of Chicago Press.

Taylor, John B. and Volker Wieland (2012), Surprising Comparative Properties of Monetary Models: Results from a New Model Data Base, Review of Economics and Statistics,94 (3), August 2012, pp. 800-816.

Yellen, Janet (2015), “Normalizing Monetary Policy: Prospects and Perspectives,” Remarks at the conference on New Normal Monetary Policy, Federal Reserve Bank of San Francisco. 


\section{IMFS WORKING PAPER SERIES}

\section{Recent Issues}

$\begin{array}{ll}102 \text { / } 2016 & \begin{array}{l}\text { Tilman Bletzinger } \\ \text { Volker Wieland }\end{array} \\ 101 / 2016 & \text { Helmut Siekmann } \\ 100 \text { / } 2016 & \begin{array}{l}\text { Robert C. M. Beyer } \\ \text { Volker Wieland }\end{array}\end{array}$

99 / $2015 \quad$ Helmut Siekmann

98 / $2015 \quad$ Helmut Siekmann
97 I $2015 \quad$ José María Liberti Amit Seru
Vikrant Vig

96 / $2015 \quad$ Patrick Tuschl

$95 / 2015$

Athanasios Orphanides

94 / 2015

$93 / 2015$

92 / 2015

$91 / 2015$

$90 / 2015$

Roman Inderst

Marcus Opp

Helmut Siekmann
Forward guidance and "lower for longer": The case of the ECB

Ziele, Aufgaben und Befugnisse des Europäischen Systems der Zentralbanken (ESZB)

Schätzung des mittelfristigen Gleichgewichtszinses in den Vereinigten Staaten, Deutschland und dem Euro-Raum mit der Laubach-Williams-Methode

Exit, Exclusion, and Parallel Currencies in the Euro Area

Stellungnahme für die öffentliche Anhörung der Verfassungskommission des Landtags Nordrhein-Westfalen zur Schuldenbremse

Information, Credit, and Organization

Rechtsgrundlagen für die Vereinbarkeit von Finanzhilfen für Kreditinstitute mit dem Beihilferecht der EU im Rahmen der Finanzmarktkrise

Fear of Liftoff: Uncertainty, Rules and Discretion in Monetary Policy Normalization

Aggregate and Distributional Effects of Increasing Taxes on Top Income Earners

Regulatory Influence on Market Conditions in the Banking Union

How Organizational Hierarchy Affects Information Production

Regulating Deferred Incentive Pay
The Legality of Outright Monetary Transactions (OMT) of the European System of Central Banks (publ. in: Rövekamp / Bälz / Hilpert (eds.), Central Banking and Financial Stability in East Asia, 2015, pp. 101-123) 
89 / $2015 \quad$ Helmut Siekmann

Florian Deuflhard

Dimitris Georgarakos

Roman Inderst

87 I $2015 \quad \begin{array}{ll}\text { Falko Fecht } \\ \text { Roman Inderst } \\ \text { Sebastian Pfeil }\end{array}$

86 / $2015 \quad$ Markus Behn

Rainer Haselmann

Thomas Kick

Vikrant Vig

85 / $2014 \quad \begin{aligned} & \text { Elena Afanasyeva } \\ & \text { Jochen Güntner }\end{aligned}$

84 / $2014 \quad$ Athanasios Orphanides

$83 / 2014$

Tobias H. Tröger

82 / 2014

$81 / 2014$

$80 / 2014$

$79 / 2014$

Athanasios Orphanides

$78 / 2014$

$77 / 2014$

$76 / 2013$

Rainer Haselmann

Vikrant Vig

Volker Wieland

Maik Wolters

Hermann Remsperger

Marcel Bluhm
The Legal Framework for the European System of Central Banks (publ. in: Rövekamp / Bälz / Hilpert (eds.), Central Banking and Financial Stability in East Asia, 2015, pp. 43-86)

Financial Literacy and Savings Account Returns

A Theory of the Boundaries of Banks with Implications For Financial Integration and Regulation

The Political Economy of Bank Bailouts

Lending Standards, Credit Booms and Monetary Policy

Are Rules and Boundaries Sufficient to Limit Harmful Central Bank Discretion? Lessons from Europe

How Special Are They? - Targeting Systemic Risk by Regulating Shadow Banking

The Limits of Model-Based Regulation

Is there a threat of self-reinforcing deflation in the Euro area? A view through the lens of the Phillips curve

Der makroprudenzielle Komplex: der Prozess, das Schloss, das Urteil

What Happened in Cyprus? The Economic Consequences of the Last Communist Government in Europe

On the Conditional Effects of IMF Loan Program Participation on Output Growth

Zur Offenlegung der Bezüge von

Sparkassenführungskräften im Internet

Financial Regulation and Supervision

Across Business Lines in the United States

- Financial Holding Companies post

Gramm-Leach-Bliley Act

Is Monetary Policy Overburdened? 